\title{
Aeromonas Infections in Patients with Liver Cirrhosis in Japan
}

\section{Toru Shizuma*}

Department of Physiology, School of Medicine, Tokai University, Japan

\begin{abstract}
Aeromonas species are recognized as opportunistic pathogens that cause serious problems in patients with liver cirrhosis (LC). In this article, 25 case reports of Aeromonas infections in patients with LC in Japan are reviewed and summarized. Among the 25 cases, cases of septicemia or skin and soft tissue infections have been relatively well reported. In total, the 1 -month mortality rate was $68 \%(17 / 25)$, whereas the overall survival rate was $32 \%(8 / 25)$. In particular, among 16 cases with skin and soft tissue infections, 12 (75\%) died within the first 4 days after admission, regardless of the administration of antimicrobial agents and/or lower limb amputation, indicating extremely poor short-term prognosis.
\end{abstract}

Keywords: Aeromonas infections; Liver cirrhosis; Hepatitis

Abbreviations: DM: Diabetes Mellitus; HCV: Hepatitis C Virus; LC: Liver Cirrhosis; SBP: Spontaneous Bacterial Peritonitis

\section{INTRODUCTION}

Patients with Liver Cirrhosis (LC) are at a high risk of developing bacterial infections for several reasons, including hypoactivity of phagocytic cells in the hepatic reticuloendothelial system, decreased production of complement, bacterial translocation partially because of impaired intestinal permeability, and bacterial influx into the general circulation through portacaval shunts $[1,2]$. The most common bacterial infections identified in patients with LC are Spontaneous Bacterial Peritonitis (SBP), which is a life-threatening infection in patients with ascites; urinary tract infections; respiratory infections, particularly pneumonia, skin and soft tissue infections; and bacteremia [1].

Aeromonas species are Gram-negative, rod-shaped bacteria that are proliferative and omnipresent in both fresh water and soils $[3,4]$ and are occasionally isolated from the faeces of healthy individuals [5]. Aeromonas infection is most commonly associated with gastroenterocolitis; extra-intestinal infections, such as bacteremia, pneumonia, empyema, arthritis, endocarditis, meningitis, urinary tract infection, biliary tract infection, peritonitis, including SBP; and skin and soft tissue infections [3].

Aeromonas species are recognized as opportunistic pathogens that cause serious problems, especially septicemia in immunocompromised patients with LC, hematological malignancies, diabetes mellitus (DM), severe biliary tract diseases, and renal failure [4-7]. They also cause life-threatening skin and soft tissue infections [3] in addition to Vibrio species, particularly in patients with LC. Moreover, Aeromonas bacteremia in patients with LC or malignancy has been found to be associated with a higher mortality rate than bacteremia caused by other organisms [6]. Aeromonas-implicated clinical diseases are primarily caused by Aeromonas hydrophila, A. sobria, and A. caviae [5]. Chuang et al. [2] reported that the severity and mortality of bacteremia caused by A. caviae were lower than bacteremia caused by A. hydrophila or A. sobria. They further reported that A. caviae was less associated with LC than other species (A. hydrophila or A. sobria) [2].

Studies of Aeromonas infections complicated in patients with LC have been reported primarily in regions of East Asia, notably Taiwan and Korea, partially because of their ubiquitous presence in the environment and high incidence in chronic liver diseases [8]. However, cases of Aeromonas infections in patients with LC have only been sporadically reported in Japan. Additionally, to the best of our knowledge, there have been no review articles regarding Aeromonas infections in patients with LC in Japan. Therefore, in this article, case reports of Aeromonas infections in patients with LC in Japan both in English and Japanese (proceedings were excluded) that were retrieved from the PubMed and Japana Centra Revuo Medicina (Igaku Chuo Zasshi) databases, respectively, are reviewed and summarized. A literature search was performed using the following keywords: (1) "Aeromonas" and "liver cirrhosis," (2)

Correspondence to: Toru Shizuma, Department of Physiology, School of Medicine, Tokai University, Japan, Tel: +81-0463-93-112; E-mail: shizuma@is.icc.u-tokai.ac.jp

Received: December 18, 2018, Accepted: January 16, 2019, Published: January 22, 2019

Citation: Shizuma T (2019) Aeromonas Infections in Patients with Liver Cirrhosis in Japan. Biochem Anal Biochem 8:235. doi: 10.35248/21611009.19.8.235.

Copyright: (C) 2019 Shizuma T. This is an open-access article distributed under the terms of the Creative Commons Attribution License, which permits unrestricted use, distribution, and reproduction in any medium, provided the original author and source are credited. 
"Aeromonas" and "bacteremia," and (3) "Aeromonas" and "bacterial infection."

\section{Aeromonas infections in patients with LC in Japan}

The detection frequency of Aeromonas species in blood culture has been reported to be higher in patients with LC than in the general hospitalized population [9]. In our previous study of a single facility in Japan, the detection frequency of Aeromonas species was $5.8 \%(7 / 120)$ among the total organisms detected in blood cultures of patients with LC [7], whereas another study of a single facility in Japan reported a rate of $6.8 \%(3 / 44)$ [10], whereas the rate among general hospitalized populations in Japan is reportedly $0 \%-1.9 \%$ [7]. Frequencies of A. hydrophila septicemia are reportedly $14 \%-58 \%$ among all patients with LC and Aeromonas septicemia in Japan [11]. Furthermore, we reported that the severity of liver dysfunction in Aeromonas-induced bacteremia is greater than that in Enterobacteria-induced bacteremia in Japanese patients with LC [12].

\section{Case reports of Aeromonas infections in Japan}

The clinical characteristics and prognoses of 25 reported cases of Aeromonas infections in patients with LC in Japan reported from 1992 to 2016 are summarized in Table 1. Among the 25 cases, three were reported in English $[4,13,14]$ and the remaining 22 in Japanese [9,11,15-31]. The age at diagnosis of Aeromonas infection ranged between 40 and 78 years, and 19 patients were male and five were female with one case unknown. The etiology of LC was as follows: hepatitis $\mathrm{C}$ virus (HCV) infection in six cases [13,21,22,25,29], hepatitis $\mathrm{B}$ virus infection in six $[9,11,16,26,27,30]$, alcohol-related in nine $[4,14,15,17,20,21,23,28,31] \mathrm{HCV}$ infection plus alcoholrelated in one [22], and unknown in three $[18,19,24]$. The ChildPugh classification of underlying liver dysfunction was as follows; Child C in nine, Child B in one, and unknown in 15 cases.

Table 1: Clinical characteristics and outcomes in the 25 reported cases of Aeromonas infections in patients with liver cirrhosis in Japan.

\begin{tabular}{|c|c|c|c|c|c|c|c|c|}
\hline Case & $\begin{array}{c}\text { Age } \\
\text { (years) }\end{array}$ & $\begin{array}{l}\text { Isolated } \\
\text { species }\end{array}$ & Types of infection & $\begin{array}{l}\text { Child-Pugh } \\
\text { classification }\end{array}$ & $\begin{array}{l}\text { Underlying } \\
\text { diseases }\end{array}$ & Treatments & Outcomes & Reference \\
\hline 1 & 55 & A. sobria & Necrotizing fasciitis & $\mathrm{C}$ & DM & Ceftizoxime, Minocycline & Death within 2 days & {$[17]$} \\
\hline 2 & 55 & A. hydrophila & Septicemia, Necrotizing fasciitis & Uncertain & $\mathrm{DM}$ & Benzylpenicillin & Death within 2 days & [18] \\
\hline 3 & 60 & A. sobria & Septicemia, Necrotizing fasciitis & Uncertain & $\mathrm{DM}$ & Antimicrobial agents & Death within a day & [19] \\
\hline 4 & 54 & A. hydrophila & Septicemia & $\mathrm{C}$ & - & Ampicillin, Gentamicin & Death within 2 days & [20] \\
\hline 5 & 52 & A. sobria & Septicemia, Necrotizing fasciitis & Uncertain & - & Lower limb amputation & Death within a day & [21] \\
\hline 6 & 58 & A. hydrophila & $\begin{array}{c}\text { Septicemia, Skin and soft tissue } \\
\text { infections }\end{array}$ & Uncertain & - & Antimicrobial agents & Death within a day & [21] \\
\hline 7 & 55 & A. hydrophila & Septicemia & Uncertain & - & Fosfomycin, Amikacin & Alive & [22] \\
\hline 8 & 62 & A. hydrophila & Septicemia, Empyema & C & - & Ceftizoxime & Alive & [22] \\
\hline 9 & 54 & A. hydrophila & Septicemia & $\mathrm{C}$ & $\begin{array}{c}\text { DM, Iliac } \\
\text { artery } \\
\text { aneurysm }\end{array}$ & Imipenem/Cilastatin & Alive & [22] \\
\hline 10 & 49 & A. sobria & Septicemia, Necrotizing fasciitis & Uncertain & - & Imipenem, Minocycline & Death within 2 days & {$[4]$} \\
\hline 11 & 49 & A. sobria & $\begin{array}{c}\text { Septicemia, Skin and soft tissue } \\
\text { infections }\end{array}$ & Uncertain & - & Imipenem, Minocycline & Death within 2 days & [23] \\
\hline 12 & 40 & A. hydrophila & Pneumonia & Uncertain & $\begin{array}{l}\text { Chronic } \\
\text { renal failure }\end{array}$ & Panipenem/Betamipron & Death within 2 days & [13] \\
\hline 13 & 57 & A. hydrophila & $\begin{array}{c}\text { Septicemia, Skin and soft tissue } \\
\text { infections }\end{array}$ & Uncertain & $\mathrm{DM}$ & $\begin{array}{l}\text { Imipenem/Cilastatin, } \\
\text { Clindamycin }\end{array}$ & Alive & [24] \\
\hline 14 & 69 & A. hydrophila & $\begin{array}{c}\text { Septicemia, Skin and soft tissue } \\
\text { infections }\end{array}$ & Uncertain & - & Cefpirome, Minocycline & Death within 2 days & [25] \\
\hline 15 & 67 & A. hydrophila & Bacterascites? & Uncertain & - & Uncertain & Death within 2 days & [15] \\
\hline 16 & 59 & A. hydrophila & Septicemia, Necrotizing fasciitis & Uncertain & - & Cefditoren Pivoxil & Death within 2 days & [11] \\
\hline 17 & 66 & A. hydrophila & Septicemia, Necrotizing fasciitis & $\mathrm{C}$ & - & $\begin{array}{c}\text { Ceftriaxone, Lower limb } \\
\text { amputation }\end{array}$ & Death within 4 days & [26] \\
\hline 18 & 53 & A. hydrophila & $\begin{array}{l}\text { Septicemia, Skin and soft tissue } \\
\text { infections, Bacterascites? }\end{array}$ & $\mathrm{C}$ & - & Antimicrobial agents (-) & Death within a day & {$[16]$} \\
\hline 19 & 54 & A. hydrophila & $\begin{array}{c}\text { Septicemia, Skin and soft tissue } \\
\text { infections }\end{array}$ & $\mathrm{C}$ & - & $\begin{array}{l}\text { Imipenem/Cilastatin, } \\
\text { Amikacin }\end{array}$ & $\begin{array}{l}\text { Death within } 4 \\
\text { weeks }\end{array}$ & [27] \\
\hline 20 & 50 & A. hydrophila & Septicemia & $\mathrm{C}$ & $\mathrm{DM}$ & Imipenem/Cilastatin & Alive & [9] \\
\hline 21 & 63 & A. sobria & Septicemia, Necrotizing fasciitis & Uncertain & DM & Meropenem & Death within 2 days & [28] \\
\hline 22 & 63 & A. hydrophila & Septicemia, Necrotizing fasciitis & $\mathrm{C}$ & - & $\begin{array}{l}\text { Levofloxacin, Ceftazidime, } \\
\text { Lower limb amputation }\end{array}$ & Alive & [29] \\
\hline 23 & 71 & A. hydrophila & Septicemia & B & 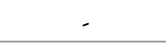 & Meropenem, Teicoplanin & Alive & [14] \\
\hline 24 & 78 & A. hydrophila & Septicemia & Uncertain & $\begin{array}{l}\text { Malignant } \\
\text { lymphoma }\end{array}$ & Tazobactam/Piperacillin & $\begin{array}{l}\text { Death within } 3 \\
\text { weeks }\end{array}$ & [30] \\
\hline 25 & 61 & A. hydrophila & Septicemia, Necrotizing fasciitis & Uncertain & - & $\begin{array}{l}\text { New quinolone, Lower } \\
\text { limb amputation }\end{array}$ & Alive & [31] \\
\hline
\end{tabular}


A. hydrophila was isolated in 19 (76\%) cases $[9,11,13-16,18,20-22,24$ 27,29-31] and A. sobria in 6 (24\%) $[4,17,19,21,23,28]$; no cases involving A. caviae was found. Consumption of Japanese cuisine, such as sashimi and sushi, were the cause of infection in $9(36 \%)$ cases $[11,17,21-23,27-29,31]$ and complications of DM in 7 cases (28\%) $[9,17-19,22,24,28]$. Cases of bacteremia (and septicemia) or skin and soft tissue infections caused by Aeromonas species in patients with LC have been relatively well reported. Although two cases of patients with LC with ascites positive for Aeromonas species have been reported $[15,16]$, there was no diagnosis of SBP caused by Aeromonas species in these cases because the polymorphonuclear cell count in the ascites was uncertain. One case of pneumonia caused by A. hydrophila infection of the lung tissues was found [13]. Meanwhile, septic shock and disseminated intravascular coagulation were confirmed in 18 [4,9,11,13-16,18-20,23-27,29-31] and 11 cases $[9,15-18,23,24,26,28-30]$, respectively.

In total, $15(60 \%)$ patients died within 4 days after admission and an additional 2 (8\%) within $3-4$ weeks after admission. The 1 -month mortality rate was $68 \%(17 / 25)$, whereas the overall survival rate was $32 \%(8 / 25)$. In particular, among 16 cases with skin and soft tissue infections [4,11,16-19,21,23-29,31], 13 (81.3\%) died within one month, which included 12 (75\%) within the first 4 days after admission [4,11,16-19,21,23,25,26,28], regardless of the administration of antimicrobial agents and/or lower limb amputation, indicating extremely poor short-term prognoses. The Child-Pugh classification was Child $\mathrm{C}$ in four cases and unknown in 11 cases among 15 death cases within the first 4 days after admission and Child C in four cases, Child B in one case, and unknown in three cases among 8 survival cases. Therefore, there were apparent correlations between short-term mortality and Child-Pugh classification, although the number of cases was limited in this article.

\section{CONCLUSION}

In many cases of reported Aeromonas infections, skin and soft tissue infections in patients with LC were observed to rapidly progress, leading to poor prognoses, regardless of the administration of antimicrobial agents. Moreover, the consumption of sushi and sashimi is suspected to be a source of Aeromonas infections in patients with LC in Japan. Therefore, patients with LC should be advised to avoid raw seafood as much as possible to prevent infections due to Aeromonas as well as Vibrio, species.

\section{REFERENCES}

1. Shizuma T. Spontaneous bacterial peritonitis and bacteremia in patients with liver cirrhosis. Wulfenia Journal. 2016;23:210-239.

2. Chuang HC, Ho YH, Lay CJ, Wang LS, Tsai YS, Tsai CC. Different clinical characteristics among Aeromonas hydrophila, Aeromonas veronii biovar sobria and Aeromonas caviae monomicrobial bacteremia. J Korean Med Sci. 2011;26:1415-1420.

3. Chao CM, Lai CC, Tang HJ, Ko WC, Hsueh PR. Skin and soft-tissue infections caused by Aeromonas species. Eur J Clin Microbiol Infect Dis. 2013;32:543-547.

4. Itoh H, Kuwata G, Tateyama S, Yamashita K, Inoue T, Kataoka H, et al. Aeromonas sobria infection with severe soft tissue damage and segmental necrotizing gastroenteritis in a patient with alcoholic liver cirrhosis. Pathol Int. 1999;49:541-546.

5. Wu CJ, Wu JJ, Yan JJ, Lee HC, Lee NY, Chang CM, et al. Clinical significance and distribution of putative virulence markers of 116 consecutive clinical Aeromonas isolates in southern Taiwan. J Infect. 2007; 54:151-158.

6. Choi JP, Lee SO, Kwon HH, Kwak YG, Choi SH,Lim SK, et al. Clinical significance of spontaneous Aeromonas bacterial peritonitis in cirrhotic patients: a matched case-control study. Clin Infect Dis. 2008;47:66-72.

7. Shizuma T, Obata H, Hayashi N. Aeromonas septicemia complicated with liver cirrhosis in Tokyo Women's Medical University. Kansenshogaku Zasshi. 2003;77:235-236.

8. Wu CJ, Chen PL, Tang HJ, Chen HM, Tseng FC, Shih HI, et al. Incidence of Aeromonas bacteremia in Southern Taiwan: vibrio and Salmonella bacteremia as comparators. J Microbiol Immunol Infect. 2014;47:145-148

9. Kameda T, Hasuike S, Yamaji T, Harada T, Nakamura K. A case of decompensated HBV-related liver cirrhosis complicated by septic shock due to Aeromonas hydrophila. J Miyazaki M A. 2010;34:110-115.

10. Mizuno R, Nishiyama Y, Shimizu S, Kitagawa M. Clinical study on bacteremia in patients with liver cirrhosis. Kansenshogaku Zasshi. 1996;70:456-462.

11. Tachibana Y, Asai J, Notsumata K, Toya D, Tanaka N, Matsunou H, et al. An autopsy case of sepsis due to Aeromonas hydrophila with hepatic cirrhosis type B. Nihon Shokakibyo Gakkai Zasshi. 2003;100:11111116.

12.Shizuma T, Tanaka C, Mori H, Fukuyama N. Investigation of Bacteremia due to Aeromonas Species and Comparison with That due to Enterobacteria in Patients with Liver Cirrhosis. Gastroenterol Res Pract. 2011;2011:930826.

13. Murata H, Yoshimoto H, Masuo M, Tokuda H, Kitamura S, Otsuka $\mathrm{Y}$, et al. Fulminant pneumonia due to Aeromonas hydrophila in a man with chronic renal failure and liver cirrhosis. Intern Med. 2001;40:118 123.

14. Yumoto T, Ichiba S, Umei N, Morisada S, Tsukahara K, Sato K, et al. Septic shock due to Aeromonas hydrophila bacteremia in a patient with alcoholic liver cirrhosis: a case report. J Med Case Rep. 2014;8:402.

15.Koizumi T, Murata A, Goto H, Yamaguchi Y, Sakaki S, Okazaki M, et al. Critical infection of Aeromonas hydrophila and epidemiological study. JJAAM. 2002;13:674-679.

16. Miyakawa Y, Tsuiki H, Kogi M, Iizawa T, Kamimura A. A case of fulminant Aeromonas hydrophila infection with liver cirrhosis by hepatitis B virus. J Iwamizawa Hosp. 2007;33:15-19.

17. Furuki H, Mizutari K, Maekawa Y, Nogami R. A case of necrotizing fasciitis caused by Aeromonas sobria. Jpn J Dermatol. 1992;102:847-850.

18. Fukui S, Ogata R, Fujigaki T, Nakamura H, Haseba S. A severe case of Aeromonas hydrophila sepsis which developed disseminated intravascular coagulation and multiple organ failure. ICU\&CCC. 1992;16:995-1002.

19. Takaba M, Gusima Y, Kukita T, Tokunaga K, Fukuda Y. A case of necrotizing fasciitis caused by Aeromonas sobria with diabetes and liver cirrhosis. Naika. 1994;74:981-983.

20.Yokoba M, Shirasaki K, Aoki N, Soma K. A case of severe acute hepatorenal failure due to Aeromonas hydrophila septicemia. Kansenshogaku Zasshi. 1996;70:1111-1115.

21. Tateyama S, Miyaguni H, Tsumori S, Era K, Ogata K. Three fatal cases of soft tissue infection with Vibrio vulnificus, Aeromonas sobria, Aeromonas hydrophila, respectively in patients with liver cirrhosis. Nishinihon J Dermatol. 1998;60:653-659.

22.Tabata A, Hatayama M, Shimizu Y. Three cases of Aeromonas hydrophila septicemia complicated with hepatic cirrhosis. Nihon Shokakibyo Gakkai Zasshi. 1999;96:1181-1185.

23.Naruo H, Hirabe T, Urabe H, Ohkura T, Kusumoto K. A case of 
necrotizing soft tissue infection due to Aeromonas sobria. J Jpn Soc Intensive Care Med. 2000;7:135-139.

24. Morita O, Ogose A, Hotta T, Hoshino M, Shiozaki H. Therapeutic experience of necrotizing fasciitis of lower leg caused by Aeromonas hydrophila. Arch Niigata Soc Orthop Surg. 2001;17:77-80.

25.Saeki H, Matsuda N, Tamura T, Masuda N, Yonei A. A case of severe septicemia due to Aeromonas hydrophila. Masui. 2002;51:193-195.

26.Suzumura K, Sugimoto T, Fujimoto J. Fatal Aeromonas hydrophila infection in a patient with liver cirrhosis. Kanzo. 2007;48:317-321.

27. Nakano E, Hirabayashi K, Shimoura S, Takai T, Murata Y. A case of necrotizing fasciitis caused by Aeromonas hydrophila. Skin Research. 2009;8:428-434.
28. Iwakura T, Yoshida S. Fatal Aeromonas sobria infection in liver cirrhosis. Kansenshogaku Zasshi. 2011;85:512-514.

29. Onizawa S, Ito S. A case of necrotizing fasciitis caused by Aeromonas hydrophila which could be life-saving by lower limb amputation. Rinsho derma (Tokyo). 2013;55:1359-1362.

30.Tanaka M, Watanabe N, Aota Y, Ando J, Gotoh A, Komatsu N. Septic shock and necrotizing fasciitis due to Aeromonas hydrophila after chemotherapy in a patient with mantle cell lymphoma accompanied by liver cirrhosis. Rinsho Ketsueki. 2014;55:2433-2436.

31. Okada Y, Zenke Y, Shimazu D, Yasui K, Yamanaka Y, Sakai A. A case of necrotizing fasciitis caused by Aeromonas hydrophila which was difficult to discriminate between necrotizing fasciitis and severe cellulitis at initial diagnosis. Orthopedics \& Traumatology. 2016;65:316-319.8. 